\title{
COMPARATIVE ANALYSIS OF PAVEMENT RECONSTRUCTION METHODS
}

\author{
Alexander Kuleshov \\ "Trasstroy" LLC \\ 187556, Leningrad region, Tikhvin, 3 microdistrict, 5, Russia
}

89216306314@yandex.ru

\begin{abstract}
The article deals with pavement reconstruction methods. Hot and cold recycling technologies are compared. Such technologies ensure significant savings compared to complete reconstruction and placement of additional layers on top of the existing pavement.

They also allow restoring road pavements according to high quality standards, within the shortest time possible and with minimum impact on the pavement. Examples of implemented pavement reconstruction projects using recycling are
\end{abstract} given.

\author{
Keywords \\ Pavement reconstruction, recycling, recycler, Remix.
}

\section{Introduction}

One of the most pressing issues both in Russia and abroad is deterioration of road pavements. The existing network of motor roads in the Russian Federation has poor transport and operational conditions. At the present time, $80 \%$ of roads in the Russian Federation need urgent repair.

Considering the fact that only $20 \%$ of road maintenance requirements regarding repaving are funded, it is necessary to determine the best option of road pavement repair.

Currently, the following methods are the most common in rehabilitation of flexible pavements:

- hot and cold recycling technologies;

- a conventional technology which involves removal of the existing pavement and construction of a new one at the same place or placement of additional layers on top of the existing pavement;

- road surfacing using mastic asphalt concrete.

According to economic evaluations, low efficiency of conventional options for rehabilitation of flexible pavements was revealed (Wirtgen, 2012).

Application of road surfacing technologies using mastic asphalt concrete is a rather expensive road repair option.
As a consequence, it is very rarely used in road repair or reconstruction in Russia.

An option for rehabilitation of flexible pavements using cold recycling has the following advantages over complete reconstruction and placement of additional layers on top of the existing pavement:

- cost efficiency;

- high quality of rehabilitated pavements;

- short construction duration;

- minimum pavement deformation.

For those reasons, cold recycling is widely used in various countries (Wirtgen, 2012; Shipitsyn, 2006).

Besides cold recycling, hot recycling is used, when the existing asphalt concrete is heated using infrared rays and then hot-milled. After that it is loosened, re-spread and compacted.

However, hot recycling has several significant disadvantages:

- asphalt concrete heating using infrared rays causes considerable damage to the environment;

- a large amount of energy is spent during asphalt concrete heating, which makes this technology economically unprofitable;

- low durability of rehabilitated pavements. 
Given the disadvantages stated above, in the late 1980s, many Western European countries almost abandoned rehabilitating flexible pavements using hot recycling, and cold recycling came to the fore.

\section{Recycling technologies}

Currently, both in the Russian Federation and abroad, cold recycling is widely used during road pavement repair and reconstruction. This technology allows using old pavement material most efficiently and minimizing damage to the environment. However, cold recycling poses the following problem: is is almost impossible to determine the thickness of the reclaimed layer without obtaining the stress-strain state. Problem solving according to the current standards does not allow taking into account the spatial nature of load applied by modern road trains, physical and geometric nonlinearity, and behavior of layer materials.

Repair requires significant financial resources which usually are not enough. An issue of innovation implementation to reduce repair and reconstruction costs with no compromise in quality becomes more pressing.

The existing approach applied in designing and conducting of road repair and roadway replacement works does not always allow using funds allocated for such purposes efficiently. It is assumed at this stage that road replacement shall include not only replacement of the wearing course but also replacement of the base course since not so much pavement condition as its bearing capacity can serve as a justification for road replacement.

As a result, in some cases design companies understate the actual results of pavement strength tests to justify the need for road replacement at a particular road section. While reconstruction of the base course at such sections is not necessary during road replacement, it is performed anyway.

At the same time, if a road section has sufficient bearing capacity and road replacement is required due to poor pavement condition, it is possible to use repair options which are twice more efficient than replacement of the existing base course.
Cold recycling is a modern progressive technology of pavement rehabilitation, involving milling of worn-out pavement, mixing of the milled pavement with binders and placement of a new pavement at the same place, followed by its compaction and arrangement of a finish layer. It is impossible to use cold recycling without a recycler - a special machine with a milling and mixing drum as the main working body (Figure 1). Rotating against the direction of recycler's travel, the milling drum ensures pavement destruction, milling, and mixing with water and bitumen emulsion.

Then grading of the recycled layer using a grader and subsequent compaction with a vibrating roller are carried out. The process is finished with arrangement of a finish layer.

Three options of cold recycling are distinguished:

- in-place recycling;

- in-plant recycling;

- combined option.

In-place recycling provides for performance of all process operations directly at the site of repair and rehabilitation works (Filatov, 2009; Wirtgen, 2012,; Shipitsyn, 2006).

In-plant recycling provides for use of stationary and semi-mobile mixers. An advantage of this option is in the possibility to exert quality control over materials composing the asphalt-concrete mix.

However, in-plant recycling has a significant disadvantage - transportation costs making the technology economically unprofitable. That is why many countries have almost abandoned in-plant recycling. Meanwhile, in-place recycling and the combined option have come to the fore.

Cold recycling option selection depends on the road location, topological and hydrogeological conditions, and availability of required materials (Wirtgen, 2012).

Cold recycling is carried out using organic, inorganic and combined binders. Binder selection, as cold recycling option selection, is a very complex and important task facing engineers. Bitumen emulsion and foamed bitumen are used as organic binders. Usually,

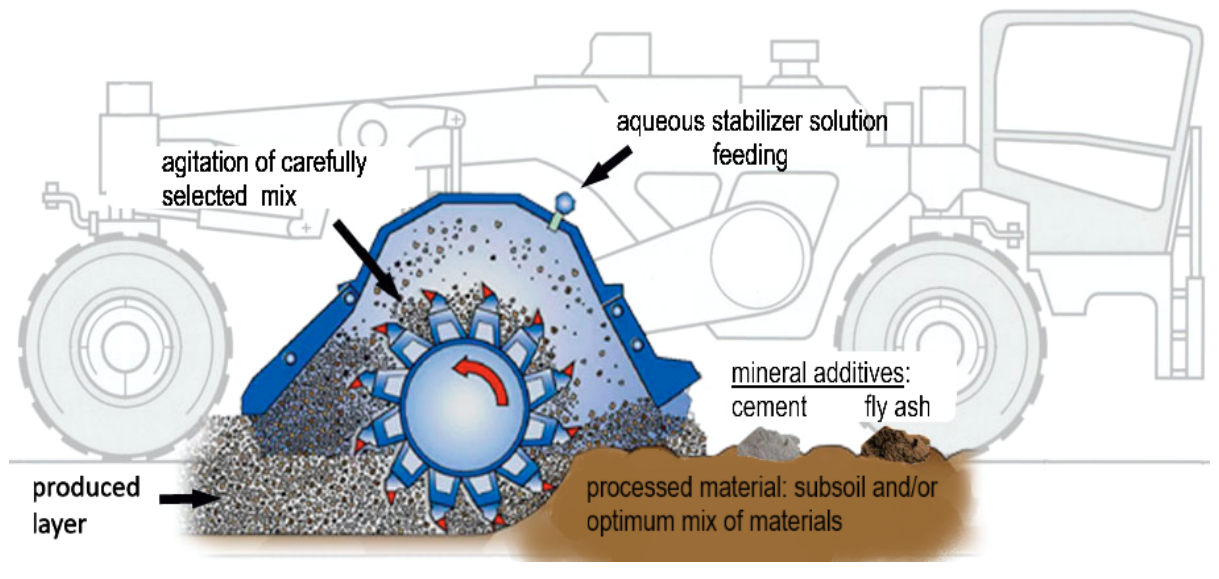

Figure 1. Recycling scheme 


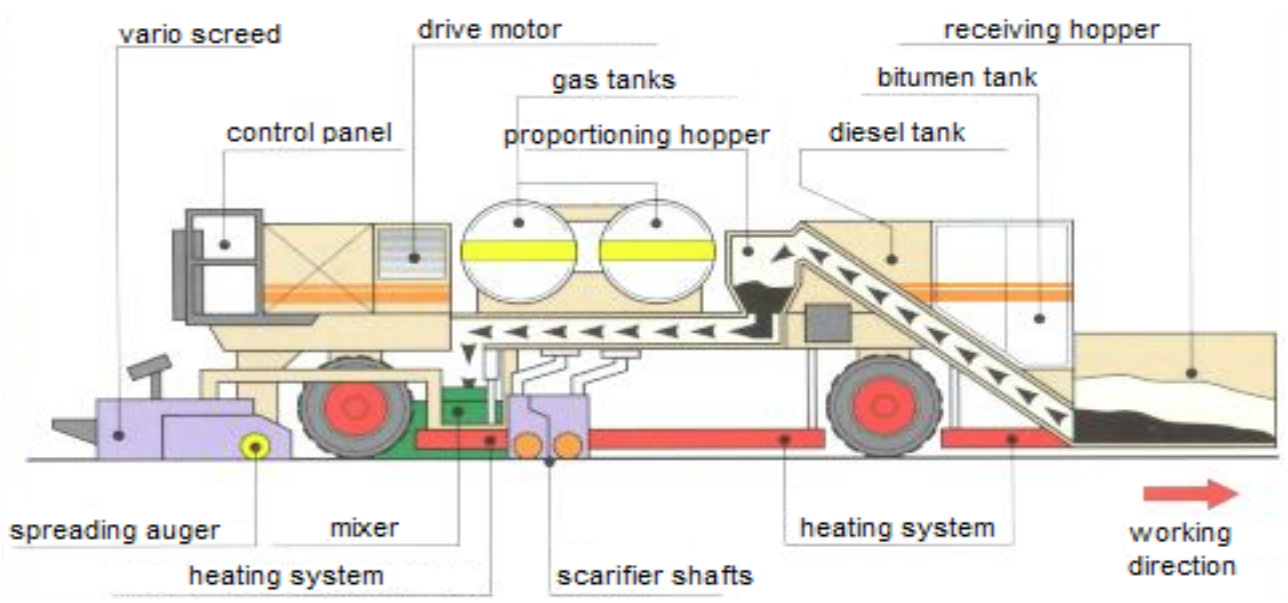

Figure 2. Asphalt-concrete pavement restoration using the Remix technology

bitumen emulsion is $60 \%$ bitumen and $40 \%$ water. However, the bitumen concentration can vary from 30 to $70 \%$.

The use of foamed bitumen is accompanied by foaming with addition of water (approximately $2 \%$ of the total mass) at a binder temperature of $160 \ldots 180^{\circ} \mathrm{C}$. In this case, water expands 1,500 times as compared to its initial state.

As for inorganic binders, cement or lime can be used. Those binders are added with the sole purpose to increase the pavement compressive strength.

Currently, a combined binder (bitumen emulsion + water-cement suspension) is widely used both in Russia and abroad (AASHTO, 2004). Pavements made of milled asphalt concrete reinforced with a complex binder have higher resistance to deformation. This is due to the fact that in this material both coagulation and crystallization bonds are formed.

\section{Contemporary challenges of hot asphalt-concrete recycling}

Introduction of recycling processes, i.e. re-use of used materials, is an effective solution to problems of natural resources saving and waste recycling. One of important recycling objects is the asphalt-concrete pavement material. According to the data of L. Santucci (Santucci, 2007), the annual volume of asphalt-concrete recycling in the USA exceeds the total recycling volume of other strategically important materials (aluminum, plastic, paper, and glass).

The material of removed asphalt-concrete pavements can be used as a filler in road reconstruction and replacement. Mechanical manipulation of asphalt concrete allows obtaining high-quality material meeting applicable standards, which consists of a mineral part and a bituminous binder, and serves as a secondary raw material containing bitumen for RAM (recycled asphaltconcrete mix) production.

In 2011, the amount of reclaimed asphalt pavement (hot asphalt-concrete recycling) in the USA was $66.3 \mathrm{mln}$ tons. It conserved more than $3.3 \mathrm{mln}$ tons of asphalt binder (Acott, 2013). For a long time, the recommended content of the secondary raw material containing bitumen in RAM was limited to $25 \%$ due to economic reasons; in some cases, it was limited to $15 \%$ (for example, upon implementation of large-scale projects). In most cases, RAM were not recommended for the arrangement of the wearing course in asphalt-concrete pavements (Kandhal, 1997).

Two types of hot recycling can be distinguished: hot in-plant recycling with preparation of asphalt concrete mixes and hot in-place recycling.

Hot in-plant recycling with preparation of asphalt concrete mixes includes the following stages: removal of old asphalt concrete using milling, delivery to the plant, storage of asphalt-concrete granulated material, production of recycled asphalt-concrete mixes, their placement and compaction (Acott, 2013).

Hot in-place recycling is based on loosening of the heated asphalt-concrete pavement and its re-use; all operations are performed using special machines directly in situ. Restoration of worn-out asphalt-concrete pavements using hot recycling is performed with Remix and Remix Plus methods.

The Remix method is used for restoration of worn-out asphalt-concrete pavements by means of their recycling and improvement of their structural as well as physical and mechanical properties. The technology involves softening of the asphalt-concrete pavement with heat, its loosening to a depth of 60 $\mathrm{mm}$, mixing of the obtained mix with additives (virgin mix, rock materials, plasticizers, mineral and organic binders), re-spreading, fixing and pre-compacting of the homogeneous recycled mix, maintaining necessary leveling and design pavement slopes in one passe of a remixer (Figure 2).

The Remix method is divided into the following options:

- thermal homogenization;

- thermal mixing;

- thermal plasticization.

Thermal homogenization involves asphalt-concrete recycling by means of heating, loosening, mixing, re- 


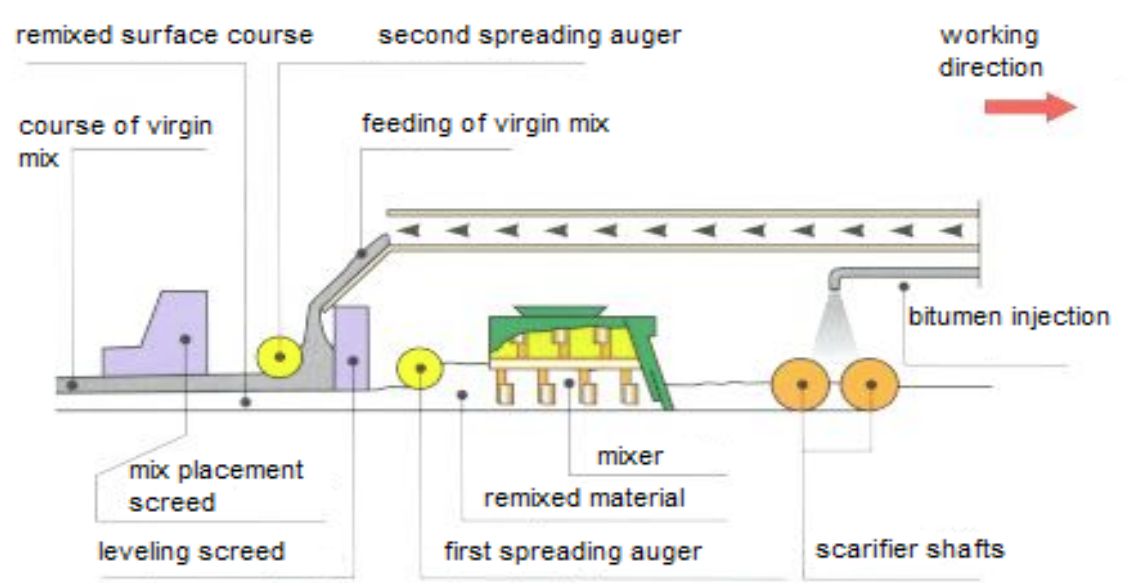

Figure 3. Asphalt-concrete pavement restoration using the Remix Plus technology

spreading and compacting of the old asphalt-concrete mix with a thickness of $3.0 \ldots 6.0 \mathrm{~cm}$.

This option is the most efficient, since it requires the minimum amount of virgin mix (about $20 \mathrm{~kg} / \mathrm{m}^{2}$ ) or does not require it at all.Thermal plasticization involves introduction of plasticizer additives into the pre-heated and loosened asphalt-concrete mix during its mixing. Liquid petroleum products are used as plasticizers. Virgin mix is added in minimum amounts - up to $20 \mathrm{~kg} / \mathrm{m}^{2}$.

Thermal mixing involves mixing of virgin mix with the old one after its heating and loosening, and fixing of the resulting mix in one layer. Thermal mixing has all advantages of thermal placement and ensures high quality of the reclaimed layer. The Remix Plus (thermal placement) method involves restoration of worn-out asphalt-concrete pavements by fixing two layers in one pass of a remixer (the lower layer made of the recycled mix and the upper layer as an additional layer).

The technology involves softening of the old asphaltconcrete pavement with heat to a depth of $60 \mathrm{~mm}$, its loosening, mixing with additives (virgin mix, rock materials, plasticizers, mineral and organic binders), and placement maintaining necessary pavement leveling; an additional course of virgin mix with a thickness of $3.0 \ldots 6.0 \mathrm{~cm}$ is laid (Figure 3).

Almost $90 \%$ of Russian public road need to be replaced. Therefore, the issue of applying modern efficient technologies in road construction is one of the most relevant. Considering the sharp increase in the cost of road construction materials in recent years (in the past decade, the cost of bitumen increased 10 times, the cost of gravel increased 5-8 times, and the cost of asphalt-concrete mix increased by 6-8 times), thermal homogenization appears to be the most promising option of hot recycling, as it is less expensive and allows re-using road construction materials. Taking into account the available experience in introduction of thermal homogenization in our country and analysis of foreign scientific and technical publications, the following advantages over other options of repair works, intended for rapid restoration of transport and operational conditions of roads, can be noted:
- complete operation cycle in one pass of special equipment, allowing reducing consumption of technical resources;

- reduction of repair work duration;

- pavement opening to traffic almost immediately after the completion of compaction, which is especially important in urban conditions for rapid traffic recovery;

- no need for disposal of the old asphalt-concrete pavement and use of new materials for its restoration;

- no need for pavement patching and crack sealing for further repair works;

- leveling of the repaired pavement;

- preservation of the existing pavement elevation points, which is especially important in streets of settlements and on bridge crossings;

- restoration of transverse and longitudinal slopes of pavements;

- rutting elimination.

One of the main problems in repair works using inplace hot recycling is heterogeneity of the old pavement which is re-used after mixing. Heterogeneity of the old pavement is due to the fact that during its operation it was repeatedly repaired using various technologies and materials.

Such heterogeneity can cause premature destruction of the repaired pavement, therefore, it is reasonable to arrange an additional layer at sections strongly affected by potholes after recycling. Issues of environmental safety during in-place hot recycling and the service life of pavements repaired using thermal homogenization need to be considered as well.

Considering that the cost of thermal homogenization depends significantly on gas consumption for pavement heating (in case of heating with infrared burners), which, in its turn, depends on the air temperature, wind speed and other weather conditions, it is reasonable to conduct research to reduce such energy consumption.

After consideration of engineering and cost aspects of in-place hot recycling and, in particular, thermal homogenization, it should be noted that the cost of such works is in the same price range as other options of 
repair works, therefore, when selecting an option, a more technological method shall be preferred.

Thermal homogenization has many advantages over other technologies, which were confirmed at pilot sections, but, given the limited experience in its implementation in our country, there is no accurate data on the service life of repaired pavements.

Therefore, it is necessary to continue research in this direction. Both engineering and cost aspects of thermal homogenization demonstrate its promising application upon restoration of transport and operational conditions of roads, especially in case of limited funding and the need for rapid repair and traffic recovery.

The key direction in research of hot recycling is production of standard asphalt concretes with more than $25 \%$ secondary raw material containing bitumen, which requires solving a number of tasks associated with high content of secondary high-viscosity bitumen:

- ensuring heat transfer enhancement during RAM production;

- ensuring combination of the new bitumen and secondary bitumen, which can be achieved through increase in the RAM production duration;

- ensuring proper parameters of asphalt-concrete compaction.

Possibilities of heat transfer enhancement through heat carrier temperature increase are limited.

An alternative approach is reducing the technological viscosity of binders without RAM production temperature increase. The corresponding solution is combination of hot recycling technologies and technologies for production of hot asphalt-concrete mixes at low temperatures, based on the use of organic or chemical additives (Adoryani, 1988).

Chemical additives reduce the technological viscosity of binders without changing the linear dependence of the viscosity on the temperature. Those include surfactants and combinations of surfactants with emulsifiers (Rediset WMX, Evotherm ET, Evotherm DAT, Evotherm 3G) additives. Organic additives reduce the technological viscosity of bituminous binders and change the linear dependence of the viscosity on the temperature. Such additives mainly include synthetic waxes. As for hot recycling, the most studied additive is Sasobit additive (manufactured by Sasol Wax). It is a synthetic wax which differs from paraffin waxes in bitumen by higher molecular mass and melting point.

In 2006-2012, at the National Center for Asphalt Technology (NCAT), a study on properties of asphalt concrete with the increased content of the secondary raw material containing bitumen (D'Angelo, 2008), including Sasobit modified binders, was conducted, and pilot sections with RAM placement (with a maximum grain size of the mineral part of $12.5 \mathrm{~mm}$ ) in the top layer of asphaltconcrete pavements; the temperature of RAM discharge from the mixer varied from 143 to $160^{\circ} \mathrm{C}$.

In the course of laboratory studies in accordance with ASTM D6648:01 (ASTM D6648:01, 2001), it was determined that asphalt concretes with $45 \%$ secondary raw material containing bitumen, including Sasobit modified binders, were characterized by expectedly high values of the dynamic modulus of elasticity $E$ at high temperatures, and, according to the results of fullscale tests, ensured proper IRI (International Refining Indices) and high rutting (after application of 9,400,000 cycles of uniaxial load, the average values of rutting depth were from $1.1 \mathrm{~mm}$ to $2.0 \mathrm{~mm}$ ).

When considering hot recycling implementation in the domestic road construction industry, it is necessary to solve the following tasks:

- determine the maximum allowable content of the secondary raw material containing bitumen, which would allow obtaining standard asphalt concrete of various grades without changing the requirements for bituminous binders and without use of plasticizers;

- determine the maximum allowable content of the secondary raw material containing bitumen, which would allow obtaining standard asphalt concrete of various grades without changing the requirements for bituminous binders, with application of plasticizers based on heavy petrochemical products.

When selecting the RAM composition, it should be noted that the characteristics of the recycled binder during RAM production differ from the characteristics of the binder, determined in the course of laboratory tests, since the combination of primary and secondary bitumen is incomplete during RAM production.

\section{Comparative analysis of pavement reconstruction methods}

Over time, roads deteriorate (irregularities and potholes appear) and become obsolete (the road bearing capacity becomes insufficient).

Pavement restoration requires a lot of effort: it is necessary to remove and transport the old pavement for re-use, and only then a new pavement can be laid. But it is even more difficult to increase the road bearing capacity. However, if the old pavement material is used directly on the roadbed, both tasks become significantly simpler. If the worn-out pavement is milled and crushed to the full depth, rock materials and binders are added (if necessary), everything is mixed and laid evenly, a new base is obtained, which is then compacted by rollers. This procedure requires special machines of high power and capacity, capable of milling to a depth of $300 \ldots 600 \mathrm{~mm}$, with a rotor diameter exceeding $1 \mathrm{~m}$.

Such machines are already produced by leading foreign manufacturers of road construction equipment: Caterpillar (USA), Sakai, Niigata and Komatsu (Japan), Wirtgen and Bomag (Germany), and Bitelli (Italy).

Caterpillar, Bomag and Bitelli machines are made according to the same scheme. The Wirtgen company named its technology for road reconstruction using the old pavement material "cold recycling". Machines designed for such works are called "recyclers".

Cold recycling can be used both on rural and local roads, and on federal roads, on stabilized (wearing 
course and base course) and non-stabilized (crushed stone) layers (https://os1.ru/article/6920-resayklerymashiny-dlya-rekonstruktsii-dorog).

It is a modern, well-proven and unique method of pavement repair, ensuring base course restoration with the re-use of the old pavement material. This method allows shortening the time for reconstruction and repair, reducing costs significantly. Cold recycling operations are carried out without traffic stoppage (http://sdmachinery.ru/ tehnologii/resajkling/).

In-place cold recycling has the following advantages:

1. No environmental pollution due to full utilization of the old pavement material; no need for dump sites; minimum volume of brought-in materials; minimum transportation; lowered energy consumption; reduced destructive impact of vehicles on the road network.

2. Quality of the reclaimed layer due to consistent mixing of materials obtained in situ with water and stabilizers. Liquids are introduced in exactly the right amount through the use of a microprocessor-based pump control system. The mixing process meets the highest requirements, since all components are forcibly mixed in a mixing chamber.

3. Pavement structural integrity. Cold recycling allows obtaining cohesive layers of large thickness, characterized by material homogeneity. Therefore, no liquid binders between thin pavement layers are required, which is sometimes necessary for pavements of standard structure.

4. Maintaining the soil integrity, as recycling causes less damage to low-quality soil than when standard road construction machines are used for pavement reconstruction. Usually, cold recycling is performed in one pass of a recycler with pneumatic tires which exert low pressure on the soil and cause only small deformation.

5. Reduction of construction work duration. Modern recycling machines are characterized by high efficiency of road construction, allowing for significant reduction of construction work duration in comparison with conventional methods of pavement restoration.

Reduction of construction work duration is beneficial for road users, because as a result, traffic is closed for a shorter period.

Those advantages make cold recycling the most attractive technology for pavement reconstruction by cost/ efficiency ratio. Let us perform a comparative analysis of pavement reconstruction methods (Table 1).

It is evident from the analysis that cold recycling allows excluding several operations from the process. There is no need to arrange a bypass road; works related to pavement dismantling, as well as to transportation and disposal of the obtained materials are excluded.

Arrangement of sandy and crushed-stone base courses is not required, since the existing base course is not damaged during recycling.
The number of machines involved in construction works significantly decreases (http://sdmachinery.ru/ tehnologii/resajkling/).

Table 1. Comparative analysis of pavement reconstruction methods

\begin{tabular}{|c|c|}
\hline $\begin{array}{l}\text { List of works required using } \\
\text { conventional reconstruction } \\
\text { methods: }\end{array}$ & $\begin{array}{l}\text { List of works required using } \\
\text { cold recycling: }\end{array}$ \\
\hline $\begin{array}{l}\text { - construction of a bypass } \\
\text { (temporary) road; } \\
\text { - pavement dismantling using } \\
\text { bulldozers, excavators; } \\
\text { - transportation of materials } \\
\text { obtained during dismantling } \\
\text { and their disposal; } \\
\text { - longitudinal grading; } \\
\text { - stabilization (compaction) } \\
\text { of the base course by rollers } \\
\text { and treatment with bitumi- } \\
\text { nous compositions; } \\
\text { - arrangement of a sandy } \\
\text { base course; } \\
\text { - arrangement of a crushed- } \\
\text { stone course in } 3 \text { layers } \\
\text { (fractions) with compaction of } \\
\text { each layer by rollers; } \\
\text { - tack coating with bituminous } \\
\text { compositions; } \\
\text { - arrangement of an as- } \\
\text { phalt-concrete pavement } \\
\text { (according to calculations); } \\
\text { - arrangement of shoulders } \\
\text { by soil filling with layer-by-lay- } \\
\text { er compaction; } \\
\text { - shoulders' surfacing with } \\
\text { crushed stone and their } \\
\text { treatment with bituminous } \\
\text { compositions. }\end{array}$ & $\begin{array}{l}\text { - dry loosening to the de- } \\
\text { signed depth; } \\
\text { - pavement grading using } \\
\text { graders; } \\
\text { - pavement surfacing with } \\
\text { high-strength crushed stone } \\
\text { (if base course reinforcement } \\
\text { is necessary); } \\
\text { - loosening to the designed } \\
\text { depth with bitumen emulsion } \\
\text { injection; } \\
\text { - pavement re-grading using } \\
\text { graders; } \\
\text { - compaction; } \\
\text { - arrangement of an as- } \\
\text { phalt-concrete pavement } \\
\text { (according to calculations); } \\
\text { - extension of shoulders (if } \\
\text { necessary). }\end{array}$ \\
\hline
\end{tabular}

\section{Implemented projects}

1. Construction of the base course with in-plant cold recycling. (Figure 4).

Location:

- R-22 Kaspiy road, M-4 Don road - TambovVolgograd-Astrakhan, km 1254+000 - km 1261+000, km 1265+000 - km 1272+000;

- R-216 Astrakhan-Elista-Stavropol road, km 55+000 - km 69+000. Astrakhan Region.

Implementation scope: $236701 \mathrm{~m}^{2}$.

2. Construction of the base course with cold recycling, using WP-2500 recycler, with binder addition (Figure 5). 

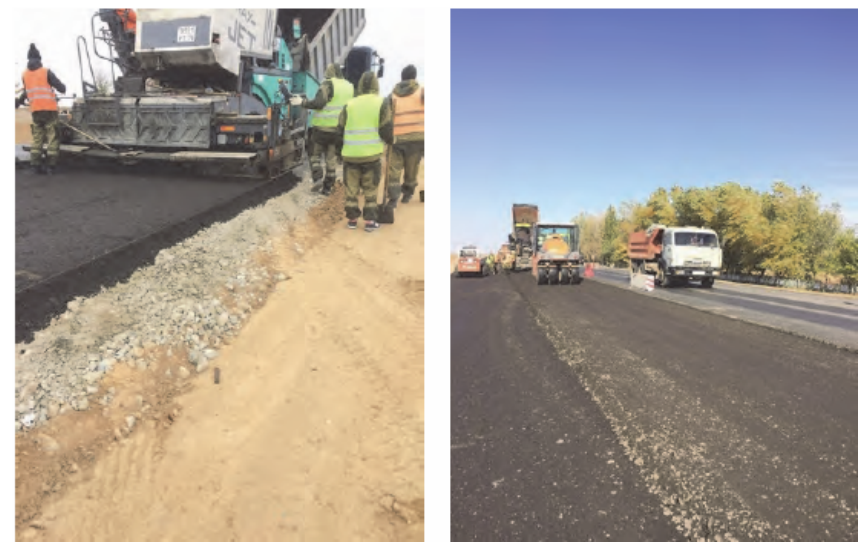

Figure 4. Construction of the base course with in-plant cold recycling (Federal Road Agency (Rosavtodor), 2016)

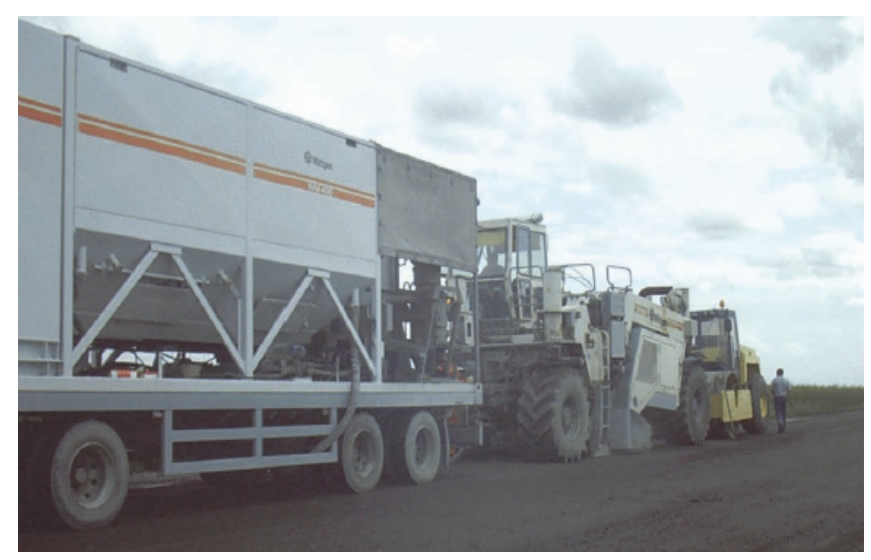

Figure 5. Construction of the base course with cold recycling (using WP-2500 recycler, with binder addition) (Federal Road Agency (Rosavtodor), 2016)

\section{Location:}

- R-22 Kaspiy road: $\mathrm{km} 848+000-\mathrm{km} 856+000$;

- R-132 Kaluga-Tula-Mikhaylov-Ryazan road: km 240+00-km 252+000.

Implementation scope: $161075 \mathrm{~m}^{2}$.

3. Cold recycling using WR-2500 Wirtgen recycler machines (complex binder: bitumen emulsion, cement) (Figure 6).

Location:

- Syktyvkar-Troitsko-Pechorsk road: LesozavodKochpon-Chit-Davpon section, km 0+000 - km 4+665;

- Syktyvkar-Troitsko-Pechorsk road: SyktyvkarPuzla-Krutaya section, km 193+000 - km 207+000.

Implementation scope: $101672.3 \mathrm{~m}^{2}$.

4. Cold recycling with addition of foamed bitumen, cement and granulated slag (Figure 7).

Location:

- Ryazan-Pronsk-Skopin road: sections km 29+230 -

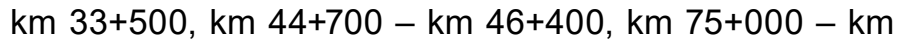
78+700, Pronsky District, Ryazan Region.

Implementation scope: $69350 \mathrm{~m}^{2}$.

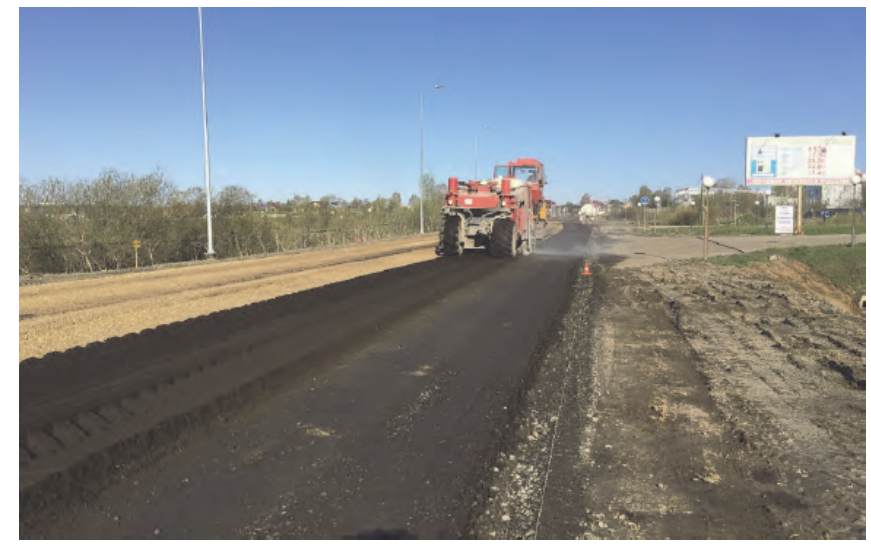

Figure 6. Cold recycling using WR-2500 Wirtgen recycler machines (complex binder: bitumen emulsion, cement) (Federal Road Agency (Rosavtodor), 2016)

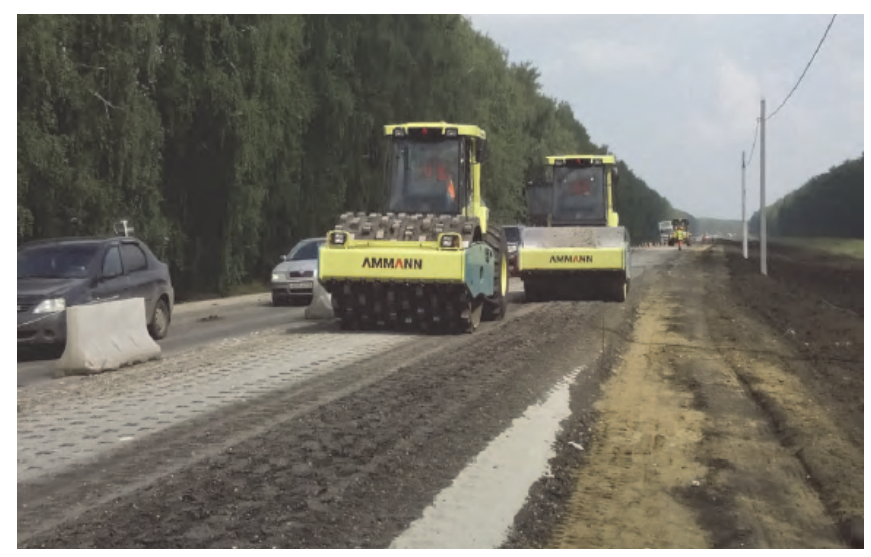

Figure 7. Cold recycling with addition of foamed bitumen, cement and granulated slag (Federal Road Agency (Rosavtodor), 2016)

\section{Conclusions}

Pavements quickly deteriorate and lose bearing capacity. One of the main issues of road construction in Russia is weak base courses which are not designed for traffic load increased in recent decades. The cold recycling technology can be referred to as a breakthrough in pavement as it allows restoring pavements without heating, re-using the removed asphalt.

But it is even more difficult to increase the road bearing capacity. Cold recycling allows obtaining a highquality road with a service life of 10-15 years, reducing construction duration by $3-5$ times and providing up to $50 \%$ of budget savings.

Meanwhile, hot recycling methods become the most efficient when ensuring the adequate service life of the road. In this case, the service life can be doubled. Besides, the cost of pavement repair during the service life is reduced by half compared to conventional methods. Moreover, all roadway defects (cracks, potholes, rutting, scaling, cracking) are eliminated during hot recycling, and the modulus of elasticity increases. 


\section{Architecture and Engineering Volume 3 Issue 1}

\section{References}

AASHTO (2004). AASHTO M323-04 Standard Specification for Superpave Volumetric Mix Design.

Acott, M. (2013). Reclaiming acclaim. Asphalt industry still leads the way in green practice. Roads \& Bridges, pp. 4-5.

Adoryani, K. (1988). Razrabotka metodov optimizatsii sostava i tekhnologii prigotovleniia obnovlennykh asfal'tobetonnykh smesei pri remonte pokrytii [Development of methods for optimization of the composition and technology for preparation of new asphalt-concrete mixes for pavement repair]. PhD thesis in Engineering. Moscow, p.15. (in Russian)

ASTM D6648:01 (2001). Standard Test Method for Determining the Flexural Creep Stiffness of Asphalt Binder Usingthe Bending Beam Rheometer (BBR), p.4.

D’Angelo, J. (2008). WarmMix Asphalt: European Practice. Report No FHWA-PL-08-007, p.68.

Gosstroy of the USSR (1989). SNIP 3.06.03-85 Avtomobil'nye dorogi. Stroitel'nye normy i pravila [Motor roads. Construction rules and regulations]. Moscow: Central Institure of Standard Designing, p.76. (in Russian)

Federal Road Agency (Rosavtodor) (2016). Catalog of efficient technologies, new materials and modern equipment for the road industry. Moscow, p.409.

Filatov, F.S. (2009). Vostanovlenie asfal'tobetonnykh pokrytii metodom kholodnogo resaiklinga [Recovery of asphalt-concrete pavements using cold recycling]. Omsk: Publishing House of the Siberian State Automobile and Highway Academy, p.72. (in Russian)

Kandhal, P., Mallick, R. (1997). Pavement Recycling Guidelines for State and Local Governments. FHWA publ. No FHWASA98-042.

Santucci, L. (2007). Recycling Asphalt Pavement - A Strategy Revisited. Tech Topic, 8, pp. 1-12.

Shipitsyn, V.V. (2006). Obosnovanie tekhnologii remonta asfal'tobetonnykh pokrytii metodom kholodnogo resaiklinga s primeneniem medlennotverdeiushchikh mineral'nykh viazhushchikh i razzhizhennogo bituma [Substantiation of the technology for asphalt-concrete pavement repair using cold recycling with application of slow-setting mineral binders and liquefied bitumen]. PhD thesis in Engineering. Omsk, p.170. (in Russian)

Wirtgen $\mathrm{GmbH}$ (2012). Wirtgen cold recycling technology. Windhagen: Wirtgen $\mathrm{GmbH}$, p.365. 